\title{
OPTIMASI DERAJAT KEANGGOTAAN FUZZY TSUKAMOTO MENGGUNAKAN ALGORITMA GENETIKA UNTUK DIAGNOSIS PENYAKIT SAPI POTONG
}

\author{
Diva Kurnianingtyas ${ }^{1}$, Wayan Firdaus Mahmudy², Agus Wahyu Widodo ${ }^{3}$ \\ ${ }^{1,2,3}$ Fakultas Ilmu Komputer Universitas Brawijaya \\ Email: ${ }^{1}$ divakurnianingtyas@gmail.com, ${ }^{2}$ wayanfm@ub.ac.id, ${ }^{3}$ a_wahyu_w@ub.ac.id \\ (Naskah masuk: 2 Februari 2017, diterima untuk diterbitkan: 27 Februari 2017)
}

\begin{abstract}
Abstrak
Sistem inferensi fuzzy bisa digunakan untuk diagnosis penyakit pada sapi potong. Untuk mendapatkan akurasi yang tinggi maka batasan fungsi keanggotaan fuzzy perlu ditentukan secara tepat. Penggunaan metode logika fuzzy untuk memperoleh hasil diagnosis penyakit pada sapi potong sesuai pakar berdasarkan batasan gejala penyakit dan aturan-aturan yang diperoleh dari pakar. Batasan tersebut bisa diperbaiki menggunakan Algoritma Genetika untuk mendapatkan akurasi yang lebih baik. Pengujian yang dilakukan pada 51 data dari beberapa gejala penyakit menghasilkan akurasi sebesar 98,04\% dengan menggunakan parameter genetika terbaik antara lain ukuran populasi sebesar 80, ukuran generasi sebesar 15, nilai Crossover rate $(\mathrm{Cr}$ ) sebesar 0,9 , dan nilai Mutation rate $(\mathrm{Mr})$ sebesar 0,06. Akurasi tersebut mengalami peningkatan sebesar 3,54\% sesudah dilakukannya optimasi pada metode logika fuzzy.
\end{abstract}

Kata kunci: diagnosis penyakit sapi potong, logika fuzzy, Algoritma Genetika

\begin{abstract}
Fuzzy inference systems can be used to diagnose cattle disease. Prior to obtaining the most accurate of limitation, fuzzy membership functions must be defined precisely. Thus, the limits will be optimized along with Genetic Algorithm to get more accurate results. The function of fuzzy logic methods in the diagnosis of disease is relied upon the parametres set by experts. Tests that were performed on 51 data from some of the symptoms of the disease resulted in an accuracy of 98.04\% using the best genetic parameters with the population size of 80 , the size of the generation of 15 , crossover rate value of 0.9 , and the value of mutation rate of 0.06 . The accuracy has increased by $3.54 \%$ compare to results before optimization.
\end{abstract}

Keywords: cattle disease diagnosis, fuzzy logic, genetic algorithms

\section{PENDAHULUAN}

Diagnosis penyakit merupakan proses awal untuk mendeteksi suatu penyakit melalui gejalagejala yang ditimbulkan. Kegagalan suatu diagnosis akan memberikan beberapa permasalahan seperti keselamatan hidup ternak (Schiff, 2008). Ternak yang sedang terjangkit penyakit, risiko hidupnya sangat bergantung terhadap diagnosis awal seorang dokter (Fernandez-Millan et al., 2015). Sehingga, ketepatan dalam mendiagnosis penyakit pada pasien sangat diperlukan.

Banyak kendala yang dialami oleh peternak sapi potong dalam mempertahankan kualitas kesehatan ternaknya. Terbatasnya pengetahuan para peternak sapi potong sehingga tidak dapat mengetahui penyakit sapi potong sejak dini (Tyas et al., 2015). Selain itu, keberadaan dokter hewan yang sangat minim untuk melakukan diagnosis sapi potong yang terserang penyakit membuat peternak lambat dalam mengambil keputusan untuk pengobatan sapi potong tersebut (Kaler and Green, 2013). Oleh karena itu, penegakkan untuk diagnosis awal merupakan hal yang penting untuk menangani penyakit. Hal itu tidak dapat dilakukan oleh peternak sapi potong.

Identifikasi dari gejala-gejala yang timbul merupakan salah satu cara untuk mendiagnosis penyakit. Permasalahan diagnosis timbul karena informasi yang tidak jelas sehingga tidak bisa menghasilkan diagnosis penyakit yang tepat (Samuel and Balamurugan, 2012). Logika fuzzy sangat fleksible pada perubahan dan ketidakpastian masalah (Purnomo and Kusumadewi, 2010). Sehingga proses diagnosis penyakit sangat cocok menggunakan logika fuzzy karena adanya ketidakjelasan informasi gejala dan penyakit. Salah satu penelitian yang dapat memberikan solusi terhadap permasalahan tersebut adalah penelitian Nisak (2015). Penelitiannya berkaitan dengan mendiagnosis penyakit sapi potong yang menggunakan metode fuzzy Tsukamoto. Pengujian dilakukan pada 26 data, memperoleh hasil akurasi sebesar 96,15\% (Nisak et al., 2015).

Logika fuzzy sudah banyak diimplementasikan untuk mendiagnosis berbagai penyakit seperti penyakit diabetes melitus tipe 2 (Meza-Palacios et al., 2017), penyakit ginjal (Ahmed et al., 2014), penyakit kulit pada anak (Putra and Munir, 2015), penyakit thyroid (Biyouki et al., 2015), dan sudden 
cardiac death (Utomo and Mahmudy, 2015) dengan mendapatkan akurasi sebesar 93,33\%, 86,7\%, 76\%, $89,09 \%$, dan $84 \%$. Tetapi penggunaan metode fuzzy ini dirasa masih kurang, beberapa penelitian mendapatkan hasil yang belum sesuai dengan ekspektasi.

Penggunaan Logika fuzzy pada permasalahan kompleks dan sangat besar, membuat proses kerjanya dirasa masih kurang optimal. Seringkali mengalami kesulitan dalam menentukan fuzzy set dan aturan fuzzy yang digunakan untuk mendapatkan solusi permasalahan (Alharbi and Tchier, 2015). Pada jurnal yang berjudul "Evolutionary Computation Based Fuzzy Membership Functions Optimization" yang ditulis oleh Esmin dan LambertTorres (2007) menyatakan bahwa metode fuzzy memiliki rule dan derajat keanggotaan yang dapat mempengaruhi kinerjanya. Sehingga dari metode fuzzy ini masih dapat dikembangkan kembali dikombinasikan dengan metode lain dengan mengubah derajat keanggotaannya. Pada kasus penelitian Nisak (2015) untuk mendiagnosis sapi potong, kemungkinan dapat dikombinasikan dengan metode lain agar mendapatkan solusi lebih optimal dengan akurasi yang meningkat.

Ada beberapa algoritma evolusi yang cocok untuk melakukan pengoptimasian derajat keanggotaan metode fuzzy. Algoritma evolusi yang dimaksud adalah Algoritma Genetika (Genetic Algorithms, GAs), Particle Swarm Optimization (PSO), dan Hybrid Particle Swarm with Mutation (HPSOM) (Esmin and Lambert-Torres, 2007). Dalam kasus Nisak (2015), penggunaan Algoritma Genetika lebih dibutuhkan. Metode ini memberikan strategi untuk menyesuaikan secara otomatis dan komparatif derajat keanggotaan. Selain itu, pada penelitian Esmin dan Lambert-Torres (2007), telah menunjukkan bahwa Algoritma Genetika memiliki performa yang lebih baik dari algoritma PSO dan HPSOM pada kasus pengoptimasian derajat keanggotaan fuzzy.

Algoritma Genetika merupakan metode yang menirukan proses evolusi biologis alamai. Algoritma ini melakukan pemilihan kromosom yang berkualitas sehingga memperoleh generasi yang berkualitas pula. Selain itu, dalam memecahkan pemasalahan yang rumit diperlukan metode dengan ruang pencarian solusi yang luas. Algoritma Genetika telah terbukti sebagai metode metaheuristic yang kuat untuk memecahkan berbagai permasalahan kompleks dengan ruang pencarian yang besar (Mahmudy, 2014). Ada beberapa penelitian yang menggunakan kombinasi metode fuzzy dan Algoritma Genetika untuk melakukan diagnosis penyakit seperti penyakit ErythematoSquamous (Parthiban and Subramanian, 2009), penyakit tubercolosis (Omisore et al., 2015), dan penyakit hepatitis (Adeli et al., 2013) sehingga dapat memperoleh akurasi sebesar 96,65\%, 60,72\%, dan $97,44 \%$. Selain diagnosis penyakit, metode tersebut dapat digunakan untuk peramalan permintaan barang (Armanda and Mahmudy, 2016) dan penentuan harga jual rumah (Azizah et al., 2015) dengan nilai error (RMSE) yang didapatkan sebesar 5779,44 dan 0,1369. Sehingga, Algoritma Genetika memperoleh hasil lebih baik dari penggunaan algoritma optimasi lainnya.

Berdasarkan penjelasan sebelumnya, penelitian ini akan mengoptimasi derajat keanggotaan dari metode fuzzy Tsukamoto menggunakan Algoritma Genetika untuk diagnosis penyakit sapi potong sehingga diharapkan permasalahan pada kasus Nisak (2015) akan memperoleh hasil yang lebih baik dan akurat.

\section{PENYAKIT SAPI POTONG}

Dalam usaha di bidang peternakan, ada beberapa penyakit yang dapat menyerang ternak sapi. Sehingga peternak seharusnya mengetahui beberapa gejala penyakit menyerang sapi yang terlihat dari tanda-tanda gejala dari ternak tersebut (Anggraeni et al., 2013). Gejala-gejala penyakit pada sapi potong terbagi menjadi gejala spesifik dan gejala non-spesifik. Gejala non-spesifik adalah gejala yang dimiliki beberapa penyakit dan memiliki tingkat gejala yaitu normal, sedang, dan tinggi. Gejala ini memerlukan sebuah metode untuk melakukan diagnosis. Gejala non-spesifik antara lain berbau busuk, bulu berdiri, bulu kusam, bulu rontok, gatal-gatal, keluar lendir vulva, kembung, kulit kasar, mamae keras, muncul belatung, pincang, dan plasenta tertinggal. Lain halnya gejala spesifik, yang hanya dimiliki oleh satu penyakit sehingga mudah untuk mendeteksi penyakit tersebut. Gejala spesifik antara lain bengkak, demam, diare, diare berdarah, keluar ingus, kurus, nafsu makan berkurang, dan sesak nafas. Berikut penjelasan beberapa jenis penyakit dan gejala-gejalanya ditunjukkan Tabel 1 .

Tabel 1. Gejala Penyakit Spesifik dan Non-spesifik Pada Sapi

\begin{tabular}{|c|c|c|}
\hline No. & Penyakit & Gejala \\
\hline 1. & Abses & Bengkak dan Demam. \\
\hline 2. & Askariasis & $\begin{array}{c}\text { Bulu kusam, Bulu berdiri, Kurus, Nafsu makan } \\
\text { berkurang, dan Diare. }\end{array}$ \\
\hline 3. & BEF & $\begin{array}{c}\text { Demam, Nafsu makan berkurang, Keluar ingus, } \\
\text { dan Pincang. }\end{array}$ \\
\hline 4. & Bloat & $\begin{array}{l}\text { Nafsu makan berkurang, Diare, Kembung, dan } \\
\text { Sesak nafas. }\end{array}$ \\
\hline 5. & Endometritis & $\begin{array}{c}\text { Demam, Nafsu makan berkurang, dan Keluar } \\
\text { lendir vulva }\end{array}$ \\
\hline 6. & Entritis & $\begin{array}{c}\text { Demam, Kurus, Nafsu makan berkurang, Diare, } \\
\text { dan Diare berdarah. }\end{array}$ \\
\hline 7. & Mastitis & $\begin{array}{c}\text { Demam, Nafsu makan berkurang, dan Mamae } \\
\text { keras }\end{array}$ \\
\hline 8. & Omphaltis & $\begin{array}{c}\text { Demam, Nafsu makan berkurang, Bengkak, dan } \\
\text { Muncul belatung. }\end{array}$ \\
\hline 9. & Pneumonia & $\begin{array}{c}\text { Demam, Nafsu makan berkurang, Keluar ingus, } \\
\text { dan Sesak nafas. }\end{array}$ \\
\hline 10. & Retensio & $\begin{array}{l}\text { Demam, Nafsu makan berkurang, Plasenta } \\
\text { tertinggal, dan Berbau busuk }\end{array}$ \\
\hline 11. & Scabies & $\begin{array}{l}\text { Bulu Rontok, Nafsu makan berkurang, Gatal-gatal, } \\
\text { dan Kulit kasar }\end{array}$ \\
\hline
\end{tabular}




\section{LOGIKA FUZZY}

Derajat keanggotaan yang dimiliki logika fuzzy antara 0 sampai 1 yang menunjukkan nilai benar atau salah (Zamroni, 2014). Pendekatan fungsi merupakan salah satu metode untuk memperoleh nilai derajat keanggotaan melalui berbagai macam representasi fuzzy (Juningdiyah et al., 2014). Kemungkinan dalam memprediksi nilai benar atau salah dalam waktu yang bersamaan merupakan karakteristik dalam fuzzy (Zamroni, 2014).

\subsection{Himpunan Fuzzy}

Himpunan fuzzy adalah suatu kelas objek dengan rangkaian nilai keanggotaan. Himpunan tersebut memiliki fungsi rentang nilai 0 sampai 1 merupakan salah satu karakteristik yang dimiliki fuzzy (Zamroni, 2014). Menurut Zamroni (2014), himpunan fuzzy dapat dinotasi ke dalam Persamaan (1).

$$
A=\{(x, \mu A(x)) \mid x \in A\}
$$

dimana $\mathrm{x}$ adalah himpunan dan $\mu A(x)$ adalah derajat keanggotaan dari $\mathrm{x}$.

\subsection{Operasi Fuzzy}

Operasi fuzzy adalah perhitungan pada himpunan fuzzy dengan mengombinasi atau memodifikasinya. Operasi tersebut diperlukan untuk proses inferensi atau penalaran. Berbagai macam operasi fuzzy dengan notasi yang ditunjukkan ke dalam persamaan antara lain (Suratno et al., 2011)
a. Kesamaan
: $\mu_{A}(x)=\mu_{B}(x), x \in X$
b. Gabungan
$: \max \left\{\mu_{A}(x), \mu_{B}(x), x \in X\right\}$
c. Irisan
$: \min \left\{\mu_{A}(x), \mu_{B}(x), x \in X\right\}$
d. Komplemen
$: \mu_{A}(x)=1-\mu_{A}(x), x \in X$

\section{FUZZY TSUKAMOTO}

Fuzzy Tsukamoto adalah salah satu jenis sistem inferensi yang memiliki fungsi keanggotaan yang monoton. Metode ini sangat fleksibel dan memiliki toleransi pada data yang sudah ada. Selain itu, fuzzy Tsukamoto lebih intuitif, diterima banyak pihak, dan lebih cocok digunakan masukan yang diterima dari manusia bukan mesin (Thamrin et al., 2014). Secara diagram proses fuzzy Tsukamoto dapat dilihat pada Gambar 1.
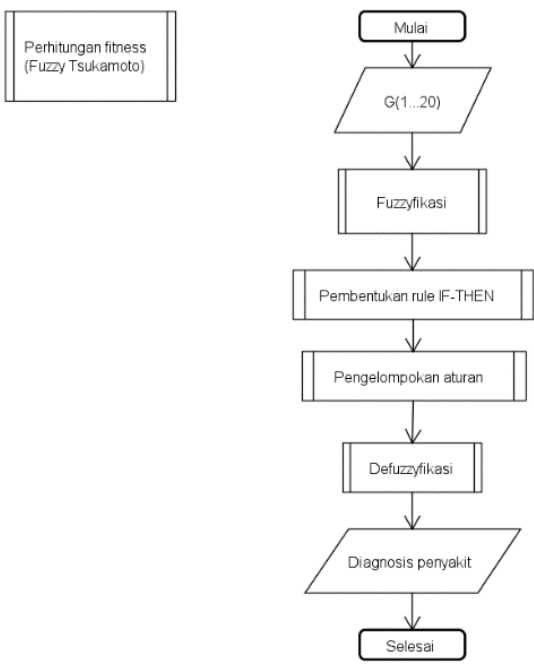

Gambar 1. Diagram Proses fuzzy Tsukamoto

\subsection{Siklus fuzzy Tsukamoto}

Tahapan pada fuzzy Tsukamoto pada Gambar 1 akan dijelaskan secara detail sebagai berikut.

1. Proses fuzzyfikasi

Dalam proses ini, input nilai pasti (crisp) diubah menjadi nilai fuzzy dengan fungsi keanggotaan. Pada penelitian ini, nilai pasti berupa nilai skor setiap gejala yang telah ditentukan. Nilai skor akan dimasukkan ke dalam fungsi keanggotaan sesuai dengan aturan domain setiap gejala. Nilai skor dan domain dibuat oleh knowledge engineer atas persetujuan pakar. Data tersebut diperoleh dari penelitian Nisak (2015) yang ditunjukkan pada Tabel 2.

Tabel 2. Nilai Skor dan Domain dari Gejala

\begin{tabular}{|c|c|c|c|c|}
\hline $\begin{array}{c}\text { Kode } \\
\text { Gejala }\end{array}$ & Gejala & Tingkat & Domain & $\begin{array}{l}\text { Nilai } \\
\text { Skor }\end{array}$ \\
\hline \multirow[t]{3}{*}{ G1 } & \multirow[t]{3}{*}{ Bengkak } & Normal & $0-50$ & 0 \\
\hline & & Sedang & $25-75$ & 60 \\
\hline & & Tinggi & $50-100$ & 95 \\
\hline \multirow[t]{3}{*}{ G2 } & \multirow[t]{3}{*}{ Demam } & Normal & $0-60$ & 0 \\
\hline & & Sedang & $50-70$ & 53 \\
\hline & & Tinggi & $60-80$ & 79 \\
\hline \multirow[t]{3}{*}{ G3 } & \multirow[t]{3}{*}{ Diare } & Normal & $0-65$ & 0 \\
\hline & & Sedang & $60-80$ & 63 \\
\hline & & Tinggi & $65-85$ & 83 \\
\hline \multirow[t]{3}{*}{ G4 } & \multirow[t]{3}{*}{ Diare berdarah } & Normal & $0-15$ & 0 \\
\hline & & Sedang & $10-20$ & 12 \\
\hline & & Tinggi & $15-30$ & 29 \\
\hline \multirow[t]{3}{*}{ G5 } & \multirow[t]{3}{*}{ Keluar ingus } & Normal & $0-60$ & 0 \\
\hline & & Sedang & $40-75$ & 55 \\
\hline & & Tinggi & $60-80$ & 79 \\
\hline \multirow[t]{3}{*}{ G6 } & \multirow[t]{3}{*}{ Kurus } & Normal & $0-30$ & 0 \\
\hline & & Sedang & $10-50$ & 21 \\
\hline & & Tinggi & $30-80$ & 77 \\
\hline \multirow[t]{3}{*}{ G7 } & \multirow{3}{*}{$\begin{array}{c}\text { Nafsu makan } \\
\text { berkurang }\end{array}$} & Normal & $0-45$ & 0 \\
\hline & & Sedang & $30-60$ & 41 \\
\hline & & Tinggi & $45-75$ & 73 \\
\hline \multirow[t]{3}{*}{ G8 } & \multirow[t]{3}{*}{ Sesak nafas } & Normal & $0-80$ & 0 \\
\hline & & Sedang & $40-90$ & 69 \\
\hline & & Tinggi & $80-100$ & 99 \\
\hline G9 & Berbau busuk & Ya & $0-100$ & 90 \\
\hline G10 & Bulu berdiri & Ya & $0-100$ & 90 \\
\hline G11 & Bulu kusam & Ya & $0-100$ & 90 \\
\hline G12 & Bulu rontok & Ya & $0-100$ & 90 \\
\hline G13 & Gatal-gatal & Ya & $0-100$ & 90 \\
\hline G14 & Keluar lendir vulva & Ya & $0-100$ & 90 \\
\hline G15 & Kembung & Ya & $0-100$ & 90 \\
\hline G16 & Kulit kasar & $\mathrm{Ya}$ & $0-100$ & 90 \\
\hline
\end{tabular}




\begin{tabular}{|c|c|c|c|c|}
\hline G17 & Mamae keras & Ya & $0-100$ & 90 \\
\hline G18 & Muncul belatung & Ya & $0-100$ & 90 \\
\hline G19 & Pincang & Ya & $0-100$ & 90 \\
\hline G20 & Plasenta tertinggal & Ya & $0-100$ & 90 \\
\hline
\end{tabular}

Sumber : Nisak (2015)

Fungsi keanggotaan akan dibentuk berdasarkan domain setiap kriteria pada rentang nilai setiap gejala. Domain yang telah dibentuk pada Tabel 2, untuk menentukan rumus fungsi keanggotaan.

2. Pembentukan aturan $I F-T H E N$.

Data 20 gejala penyakit digunakan input (masukkan) untuk mendiagnosis 11 jenis penyakit sapi potong yang memiliki parameter yang berbedabeda, antara lain:

a. G1 (Bengkak) mempunyai 3 parameter yaitu Normal, Sedang, dan Tinggi.

b. G2 (Demam) mempunyai 3 parameter yaitu Normal, Sedang, dan Tinggi.

c. G3 (Diare) mempunyai 3 parameter yaitu Normal, Sedang, dan Tinggi.

d. G4 (Diare berdarah) mempunyai 3 parameter yaitu Normal, Sedang, dan Tinggi.

e. G5 (Keluar ingus) mempunyai 3 parameter yaitu Normal, Sedang, dan Tinggi.

f. G6 (Kurus) mempunyai 3 parameter yaitu Normal, Sedang, dan Tinggi.

g. G7 (Nafsu makan berkurang) mempunyai 3 parameter yaitu Normal, Sedang, dan Tinggi.

h. G8 (Sesak nafas) mempunyai 3 parameter yaitu Normal, Sedang, dan Tinggi.

i. G9 (Berbau busuk) mempunyai 1 parameter yaitu Ya.

j. G10 (Bulu berdiri) mempunyai 1 parameter yaitu Ya.

k. G11 (Bulu kusam) mempunyai 1 parameter yaitu Ya.

1. G12 (Bulu rontok) mempunyai 1 parameter yaitu Ya.

m. G13 (Gatal-gatal) mempunyai 1 parameter yaitu Ya.

n. G14 (Keluar lendir vulva) mempunyai 1 parameter yaitu Ya.

o. G15 (Kembung) mempunyai 1 parameter yaitu Ya.

p. G16 (Kulit kasar) mempunyai 1 parameter yaitu Ya.

q. G17 (Mamae keras) mempunyai 1 parameter yaitu Ya.

r. G18 (Muncul belatung) mempunyai 1 parameter yaitu Ya.

s. G19 (Pincang) mempunyai 1 parameter yaitu Ya.

t. G20 (Plasenta tertinggal) mempunyai 1 parameter yaitu Ya.

Aturan yang digunakan diperoleh dari penelitian sebelumnya. Penelitian yang dilakukan oleh Nisak (2015) dengan jumlah 112 aturan.

3. Pengelompokkan aturan
Data masukkan gejala penyakit disesuaikan dengan data uji dari kombinasi penelitian Nisak (2015) dan Tyas (2015). Data uji penelitian Nisak (2015) sebanyak 26 data dan penelitian Tyas (2015) sebanyak 40 data. Karena ada beberapa data uji yang sama, maka hanya didapatkan data pengujian sebanyak 51 data. Berdasarkan 112 aturan yang dibentuk, digunakan untuk melakukan komposisi setiap aturan penyakit. Komposisinya menggunakan fungsi MIN dan operator AND yang akan dibahas sebagai berikut.

Contoh:

Input gejala:

- Demam Tinggi

- Nafsu makan berkurang Sedang

Proses:

Data input gejala dicocokkan ke dalam 112 aturan, kemudian untuk hasil pencocokkan aturan yang ditunjukkan pada Tabel 3.

Tabel 3. Hasil Aturan Sesuai Input Gejala

\begin{tabular}{|c|c|c|c|}
\hline Rule & Gejala & Fuzzyfikasi & $\begin{array}{c}\text { Diagnosis } \\
\text { Penyakit }\end{array}$ \\
\hline \multirow{4}{*}{55} & Demam Tinggi & 0,1 & \multirow{4}{*}{ BEF } \\
\hline & $\begin{array}{c}\text { Nafsu makan berkurang } \\
\text { Sedang }\end{array}$ & 0,733333333 & \\
\hline & Keluar ingus Sedang & 0,857142857 & \\
\hline & Pincang & 0,1 & \\
\hline \multirow{3}{*}{56} & Demam Tinggi & 0,1 & \multirow{3}{*}{ BEF } \\
\hline & $\begin{array}{l}\text { Nafsu makan berkurang } \\
\text { Sedang }\end{array}$ & 0,733333333 & \\
\hline & Keluar ingus Sedang & 0,857142857 & \\
\hline \multirow[b]{2}{*}{58} & Demam Tinggi & 0,1 & \multirow[b]{2}{*}{ BEF } \\
\hline & $\begin{array}{c}\text { Nafsu makan berkurang } \\
\text { Sedang }\end{array}$ & 0,733333333 & \\
\hline \multirow{3}{*}{86} & Demam Tinggi & 0,1 & \multirow{3}{*}{ Mastitis } \\
\hline & $\begin{array}{c}\text { Nafsu makan berkurang } \\
\text { Sedang }\end{array}$ & 0,733333333 & \\
\hline & Mamae Keras & 0,1 & \\
\hline \multirow[b]{2}{*}{87} & Demam Tinggi & 0,1 & \multirow[b]{2}{*}{ Mastitis } \\
\hline & $\begin{array}{c}\text { Nafsu makan berkurang } \\
\text { Sedang }\end{array}$ & 0,733333333 & \\
\hline \multirow{4}{*}{90} & Demam Tinggi & 0,1 & \multirow{4}{*}{ Omphaltis } \\
\hline & $\begin{array}{l}\text { Nafsu makan berkurang } \\
\text { Sedang }\end{array}$ & 0,733333333 & \\
\hline & Bengkak Tinggi & 0,1 & \\
\hline & Muncul Belatung & 0,1 & \\
\hline \multirow{4}{*}{91} & Demam Tinggi & 0,1 & \multirow{4}{*}{ Omphaltis } \\
\hline & $\begin{array}{c}\text { Nafsu makan berkurang } \\
\text { Sedang }\end{array}$ & 0,733333333 & \\
\hline & Bengkak Sedang & 0,6 & \\
\hline & Muncul Belatung & 0,1 & \\
\hline \multirow{3}{*}{94} & Demam Tinggi & 0,1 & \multirow{3}{*}{ Omphaltis } \\
\hline & $\begin{array}{l}\text { Nafsu makan berkurang } \\
\text { Sedang }\end{array}$ & 0,733333333 & \\
\hline & Bengkak Tinggi & 0,1 & \\
\hline \multirow{3}{*}{95} & Demam Tinggi & 0,1 & \multirow{3}{*}{ Omphaltis } \\
\hline & $\begin{array}{c}\text { Nafsu makan berkurang } \\
\text { Sedang }\end{array}$ & 0,733333333 & \\
\hline & Bengkak Sedang & 0,6 & \\
\hline \multirow{4}{*}{99} & Demam Tinggi & 0,1 & \multirow{4}{*}{ Pneumonia } \\
\hline & $\begin{array}{c}\text { Nafsu makan berkurang } \\
\text { Sedang }\end{array}$ & 0,733333333 & \\
\hline & Sesak nafas Tinggi & 0,1 & \\
\hline & Keluar ingus Tinggi & 0,1 & \\
\hline \multirow{3}{*}{101} & Demam Tinggi & 0,1 & \multirow{3}{*}{ Pneumonia } \\
\hline & $\begin{array}{c}\text { Nafsu makan berkurang } \\
\text { Sedang }\end{array}$ & 0,733333333 & \\
\hline & Sesak nafas Tinggi & 0,1 & \\
\hline \multirow{4}{*}{105} & Demam Tinggi & 0,1 & \multirow{4}{*}{ Pneumonia } \\
\hline & $\begin{array}{c}\text { Nafsu makan berkurang } \\
\text { Sedang }\end{array}$ & 0,733333333 & \\
\hline & Plasenta tertinggal & 0,1 & \\
\hline & Berbau busuk & 0,1 & \\
\hline 107 & Demam Tinggi & 0,1 & Pneumonia \\
\hline
\end{tabular}




\begin{tabular}{|l|c|c|c|}
\hline & $\begin{array}{c}\text { Nafsu makan berkurang } \\
\text { Sedang }\end{array}$ & 0,733333333 & \\
\cline { 2 - 3 } & Plasenta tertinggal & 0,1 & \\
\hline
\end{tabular}

Kemudian melakukan perhitungan $\alpha$-predikat, diperoleh dari nilai minimal hasil fuzzyfikasi setiap aturan yang cocok dengan input gejala. Proses perhitungan fuzzyfikasi untuk mencari $\alpha$-predikat menggunakan Persamaan (3), ditunjukkan sebagai berikut: (Nisak et al., 2015).

$\propto-$ predikat $=\operatorname{MIN}(\mu(g 1), \mu(g 2), . . \mu(g n))$

Setelah mendapatkan nilai $\alpha$-predikat dapat diperoleh nilai z dengan Persamaan (4) yaitu

$$
\propto-\text { predikat }=\frac{\text { batas atas }-z_{1}}{\text { batasatas }- \text { batas bawah }}
$$

Sehingga pada penelitian ini, berikut contoh perhitungan $\alpha$-predikat pada aturan ke-55 menggunakan Persamaan (3).

$$
\begin{aligned}
\propto-_{- \text {predikat }_{55}=} & \operatorname{MIN}\left(\mu_{\text {Tinggi }}(g 2) \cap \mu_{\text {Sedang }}(g 5)\right. \\
& \left.\cap \mu_{\text {Sedang }}(g 7) \cap \mu_{Y a}(g 19)\right) \\
= & M I N(0,1 ; 0,73 ; 0,85 ; 0,1) \\
= & 0,1
\end{aligned}
$$

\begin{tabular}{|c|c|c|c|}
\hline Rule & Gejala & Fuzzyfikasi & $\propto$-predikat \\
\hline \multirow{4}{*}{55} & Demam Tinggi & 0,1 & \multirow{4}{*}{0,1} \\
\hline & Nafsu makan berkurang Sedang & 0,733333333 & \\
\hline & Keluar ingus Sedang & 0,857142857 & \\
\hline & Pincang & 0,1 & \\
\hline \multirow{3}{*}{56} & Demam Tinggi & 0,1 & \multirow{3}{*}{0,1} \\
\hline & Nafsu makan berkurang Sedang & 0,733333333 & \\
\hline & Keluar ingus Sedang & 0,857142857 & \\
\hline \multirow{2}{*}{58} & Demam Tinggi & 0,1 & \multirow{2}{*}{0,1} \\
\hline & Nafsu makan berkurang Sedang & 0,733333333 & \\
\hline \multirow{3}{*}{86} & Demam Tinggi & 0,1 & \multirow{3}{*}{0,1} \\
\hline & Nafsu makan berkurang Sedang & 0,733333333 & \\
\hline & Mamae Keras & 0,1 & \\
\hline \multirow{2}{*}{87} & Demam Tinggi & 0,1 & \multirow{2}{*}{0,1} \\
\hline & Nafsu makan berkurang Sedang & 0,733333333 & \\
\hline \multirow{4}{*}{90} & Demam Tinggi & 0,1 & \multirow{4}{*}{0,1} \\
\hline & Nafsu makan berkurang Sedang & 0,733333333 & \\
\hline & Bengkak Tinggi & 0,1 & \\
\hline & Muncul Belatung & 0,1 & \\
\hline \multirow{4}{*}{91} & Demam Tinggi & 0,1 & \multirow{4}{*}{0,1} \\
\hline & Nafsu makan berkurang Sedang & 0,733333333 & \\
\hline & Bengkak Sedang & 0,6 & \\
\hline & Muncul Belatung & 0,1 & \\
\hline \multirow{3}{*}{94} & Demam Tinggi & 0,1 & \multirow{3}{*}{0,1} \\
\hline & Nafsu makan berkurang Sedang & 0,733333333 & \\
\hline & Bengkak Tinggi & 0,1 & \\
\hline \multirow{3}{*}{95} & Demam Tinggi & 0,1 & \multirow{3}{*}{0,1} \\
\hline & Nafsu makan berkurang Sedang & 0,733333333 & \\
\hline & Bengkak Sedang & 0,6 & \\
\hline \multirow{4}{*}{99} & Demam Tinggi & 0,1 & \multirow{4}{*}{0,1} \\
\hline & Nafsu makan berkurang Sedang & 0,733333333 & \\
\hline & Sesak nafas Tinggi & 0,1 & \\
\hline & Keluar ingus Tinggi & 0,1 & \\
\hline \multirow{3}{*}{101} & Demam Tinggi & 0,1 & \multirow{3}{*}{0,1} \\
\hline & Nafsu makan berkurang Sedang & 0,733333333 & \\
\hline & Sesak nafas Tinggi & 0,1 & \\
\hline \multirow{4}{*}{105} & Demam Tinggi & 0,1 & \multirow{4}{*}{0,1} \\
\hline & Nafsu makan berkurang Sedang & 0,733333333 & \\
\hline & Plasenta tertinggal & 0,1 & \\
\hline & Berbau busuk & 0,1 & \\
\hline \multirow{3}{*}{107} & Demam Tinggi & 0,1 & \multirow{3}{*}{0,1} \\
\hline & Nafsu makan berkurang Sedang & 0,733333333 & \\
\hline & Plasenta tertinggal & 0,1 & \\
\hline
\end{tabular}

Berikut ini hasil perhitungan $\alpha$-predikat yang ditunjukkan pada Tabel 4.

Tabel 4. Hasil Perhitungan $\alpha$-predikat
Berdasarkan Persamaan (4), berikut contoh perhitungan nilai hasil inferensi (z) pada aturan ke55 .

$$
\begin{aligned}
\alpha-\text { predikat }_{55} & =\frac{\text { batas atas }-z_{55}}{\text { batas atas }- \text { batas bawah }} \\
0,1 & =\frac{9-z_{55}}{9-0} \\
z_{55} & =8,1
\end{aligned}
$$

Berikut ini hasil perhitungan nilai inferensi (z) setiap rule yang sesuai dengan input gejala ditunjukkan pada Tabel 5.

Tabel 5. Hasil Perhitungan Nilai Inferensi (z)

\begin{tabular}{|c|c|c|}
\hline Rule & $\propto$-predikat & $\mathrm{Z}$ \\
\hline 55 & 0,1 & 8,1 \\
\hline 56 & 0,1 & 8,1 \\
\hline 58 & 0,1 & 8,1 \\
\hline 86 & 0,1 & 8,1 \\
\hline 87 & 0,1 & 8,1 \\
\hline 90 & 0,1 & 8,1 \\
\hline 91 & 0,1 & 8,1 \\
\hline 94 & 0,1 & 8,1 \\
\hline 95 & 0,1 & 8,1 \\
\hline 99 & 0,1 & 8,1 \\
\hline 101 & 0,1 & 8,1 \\
\hline 105 & 0,1 & 8,1 \\
\hline 107 & 0,1 & 8,1 \\
\hline
\end{tabular}

4. Proses defuzzyfikasi

Dalam menghitung nilai inferensi crisp setiap aturan menggunakan Persamaan (5), ditunjukkan sebagai berikut:

$$
Z=\frac{\sum \propto_{1} z_{1}}{\sum \propto_{1}}
$$

Proses menghitung nilai defuzzyfikasi (Z) dari nilai $\alpha$-predikat dan nilai inferensi (z) dilakukan

\begin{tabular}{|c|c|c|c|c|}
\hline Rule & $\begin{array}{c}\text { Diagnosis } \\
\text { Pakar }\end{array}$ & $\propto$-predikat & $\mathrm{z}$ & $\mathrm{Z}$ \\
\hline 55 & \multirow{3}{*}{ BEF } & 0,1 & 8,1 & \multirow{3}{*}{8,1} \\
\hline 56 & & 0,1 & 8,1 & \\
\hline 58 & & 0,1 & 8,1 & \\
\hline 86 & \multirow{2}{*}{ Mastitis } & 0,1 & 8,1 & \multirow{2}{*}{8,1} \\
\hline 87 & & 0,1 & 8,1 & \\
\hline 90 & \multirow{4}{*}{ Omphaltis } & 0,1 & 8,1 & \multirow{4}{*}{8,1} \\
\hline 91 & & 0,1 & 8,1 & \\
\hline 94 & & 0,1 & 8,1 & \\
\hline 95 & & 0,1 & 8,1 & \\
\hline 99 & \multirow{2}{*}{ Pneumonia } & 0,1 & 8,1 & \multirow{2}{*}{8,1} \\
\hline 101 & & 0,1 & 8,1 & \\
\hline 105 & \multirow{2}{*}{ Retensio } & 0,1 & 8,1 & \multirow{2}{*}{8,1} \\
\hline 107 & & 0,1 & 8,1 & \\
\hline
\end{tabular}
pada jenis penyakit yang sama. Proses defuzzyfikasi setiap jenis penyakit menggunakan rumus Persamaan (5), berikut contoh perhitungan pada penyakit BEF.

$$
\begin{aligned}
& \text { - } \quad \text { BEF (Rule 55, Rule 56, Rule 58) } \\
& \begin{aligned}
Z_{B E F}= & \frac{\propto_{55} z_{55}+\propto_{56} z_{56}+\propto_{58} z_{58}}{\propto_{55}+\alpha_{56}+\propto_{58}} \\
& =\frac{0,1 * 8,1+0,1 * 8,1+0,1 * 8,1}{0,1+0,1+0,1} \\
& =8,1
\end{aligned}
\end{aligned}
$$

Berikut ini hasil perhitungan defuzzyfikasi $(\mathrm{Z})$ setiap jenis penyakit yang ditunjukkan pada Tabel 6 .

Tabel 6. Hasil Perhitungan Defuzzyfikasi (Z) 
Dapat disimpulkan nilai proses defuzzyfikasi tertinggi sebesar 8,1 . Sehingga diagnosis penyakit pada sapi potong menggunakan fuzzy Tsukamoto adalah BEF, Mastitis, Omphaltis, Pneumonia, dan Retensio. Jika hasil diagnosis metode menghasilkan beberapa diagnosis penyakit, maka perhitungan akurasi menggunakan Persamaan (6), ditunjukkan sebagai berikut:

Akurasi uji $=$

$$
\frac{\text { total penyakit yang sesuai diagnosis pakar }}{\text { total hasil diagnosis metode }} \times
$$$$
100 \%
$$

Jika hasil diagnosis metode sesuai dengan diagnosis pakar, maka akurasi data uji tersebut bernilai 1 . Lain halnya, jika hasil diagnosis metode tidak sesuai dengan diagnosis pakar, maka nilai akurasinya bernilai 0 . Proses perhitungan terus berulang dengan cara yang sama hingga mencapai data uji ke-51.

\section{ALGORITMA GENETIKA}

Salah satu tipe di dalam evolutionary algorithm menggunakan pedoman seleksi alam untuk menemukan suatu solusi optimal yang biasa dikenal dengan Algoritma Genetika (Seetaram and Kumar, 2016). Algoritma Genetika menggunakan proses perubahan setiap individu sehingga mendapatkan hasil yang mendekati optimal (Chen et al., 2016a). Berikut diagram alir ditunjukan Gambar 2.

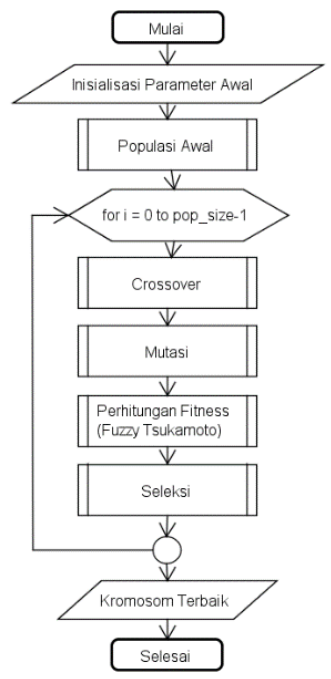

Gambar 2. Diagram Alir fuzzy Tsukamoto dan Algoritma Genetika

\subsection{Siklus Algoritma Genetika}

Tahapan pada Algoritma Genetika akan dijelaskan secara detail sebagai berikut (Ramuna and Mahmudy, 2015)s:

1. Inisialisasi

Membentuk sebuah himpunan penyelesaian terdiri dari beberapa individu di dalam populasi yang dibangkitkan secara random yang direpresentasikan ke dalam kromosom (Agarwal and Vasan, 2016).
Himpunan fuzzy diperlukan untuk menyelesaikan persoalan penelitian ini. Berdasarkan domain setiap gejala pada Tabel 2, fungsi aturan dapat terbentuk dari setiap kriteria gejala penyakit pada sapi potong. Pada gejala non-spesifik rentang nilai setiap gejala diperoleh dari batas bawah pada kriteria normal dan batas atas kriteria tinggi. Lain halnya pada gejala spesifik yang disesuaikan dengan domainnya. Sehingga, diperoleh rentang nilai setiap gejala yang ditunjukkan pada Tabel 7.

Tabel 7. Rentang Nilai Gejala Penyakit

\begin{tabular}{|c|c|c|}
\hline Kode Gejala & Gejala & Rentang Nilai \\
\hline G1 & Bengkak & $0-100$ \\
\hline G2 & Demam & $0-80$ \\
\hline G3 & Diare & $0-85$ \\
\hline G4 & Diare berdarah & $0-100$ \\
\hline G5 & Keluar ingus & $0-80$ \\
\hline G6 & Kurus & $0-80$ \\
\hline G7 & Nafsu makan berkurang & $0-75$ \\
\hline G8 & Sesak nafas & $0-100$ \\
\hline G9 & Berbau busuk & $0-100$ \\
\hline G10 & Bulu berdiri & $0-100$ \\
\hline G11 & Bulu kusam & $0-100$ \\
\hline G12 & Bulu rontok & $0-100$ \\
\hline G13 & Gatal-gatal & $0-100$ \\
\hline G14 & Keluar lendir vulva & $0-100$ \\
\hline G15 & Kembung & $0-100$ \\
\hline G16 & Kulit kasar & $0-100$ \\
\hline G17 & Mamae keras & $0-100$ \\
\hline G18 & Muncul belatung & $0-100$ \\
\hline G19 & Pincang & $0-100$ \\
\hline G20 & Plasenta tertinggal & $0-100$ \\
\hline
\end{tabular}

Kromosom yang terbentuk sejumlah 36 buah yang terdiri dari variabel parameter yang berbedabeda. Berikut contoh representasi induk parent 1 ditunjukkan Gambar 3.

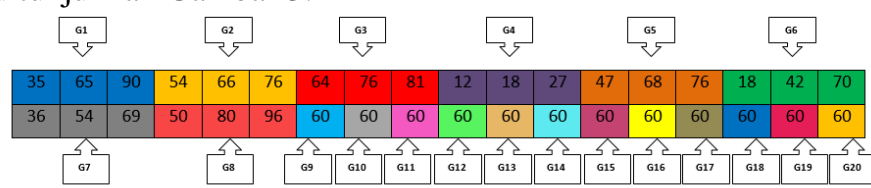

Gambar 3. Kromosom Parent 1

Berikut hasil populasi awal yang ditunjukkan pada Tabel 8.

Tabel 8. Hasil Populasi Awal

\begin{tabular}{|c|l|c|}
\hline Parent & \multicolumn{1}{|c|}{ Kromosom } & fitness \\
\hline P1 & $35,65,90,54,66,76,64,76,81,12,18,27,47,68,76$, & 0,6373 \\
& $18,42,70,36,54,69,50,80,96,60,60,60,60,60,60,60,6$ & \\
& $0,60,60,60,60$ & \\
\hline P2 & $30,70,95,52,68,78,62,78,83,11,19,28,44,71,78$, & 0,7647 \\
& $14,46,75,33,57,72,45,85,98,80,80,80,80,80,80,80,8$ & \\
& $0,80,80,80,80$ & 0,6412 \\
\hline P3 & $40,60,85,56,64,74,66,74,79,13,17,25,51,64,74$, & \\
& $22,38,65,39,51,66,55,75,94,40,40,40,40,40,40,40,4$ & \\
& $0,40,40,40,40$ & \\
\hline
\end{tabular}

\section{Reproduksi}

Proses menghasilkan keturunan individu di dalam populasi dilakukan dengan proses pindah silang dan proses mutasi. Proses pemilihan dua parent dari suatu populasi secara random atau proses pindah silang untuk menghasilkan kromosom baru disebut proses crossover (Kumar and Chatterjee, 
2016). Sedangkan, proses mutasi merupakan proses menciptakan individu baru secara random (Zhou and Song, 2016).

Penggunaan teknik two-point crossover untuk melakukan crossover. Teknik ini membutuhkan dua individu kromosom acak dan dua posisi gen acak untuk melakukan pemotongan kromosom (cutpoint). Setelah itu kromosom yang terhimpit antara posisi cutpoint ke-1 dan posisi cutpoint ke-2 akan ditukarkan dari individu ke-1 ke individu ke-2 dan sebaliknya yang telah dipilih secara acak (Kaya, 2011). Berikut ilustrasi proses two-cutpoint crossover yang akan ditunjukkan pada Gambar 4 .

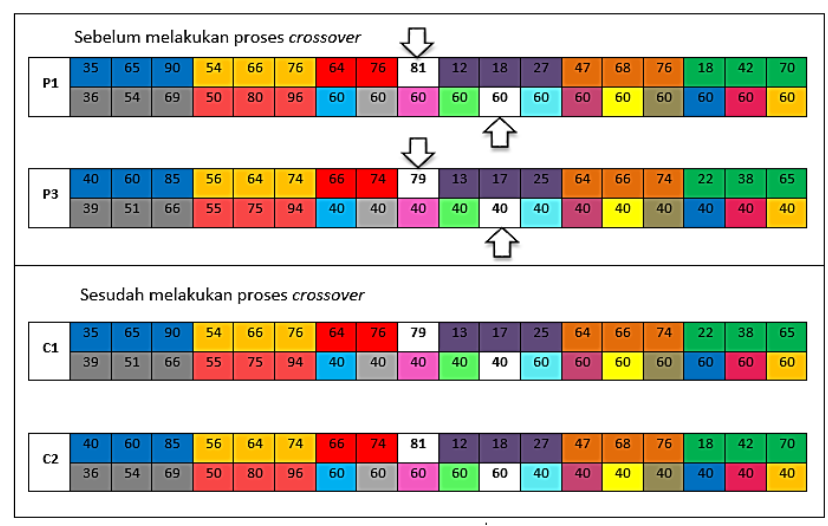

Gambar 4. Ilustrasi Proses Crossover

Hasil offspring crossover ditunjukkan Tabel 9.

Tabel 9. Hasil offspring Crossover

\begin{tabular}{|c|c|}
\hline offspring & Kromosom \\
\hline C1 & $35,65,90,54,66,76,64,76,81,13,17,25,64,66,74,22,38,65$, \\
& $39,51,66,55,75,94,40,40,40,40,40,60,60,60,60,60,60,60$ \\
\hline C2 & $40,60,85,56,64,74,66,74,79,12,18,27,47,68,76,18,42,70$, \\
& $36,54,69,50,80,96,60,60,60,60,60,40,40,40,40,40,40,40$ \\
\hline
\end{tabular}

Pada proses mutasi menggunakan teknik swap mutation dimana teknik ini dengan memperoleh dua posisi gen secara acak dari satu kromosom yang dipilih secara acak kemudian dua nilai pada posisi gen yang terpilih tersebut ditukarkan (Bala and Sharma, 2015). Berikut ilustrasi proses swap mutation yang akan ditunjukkan pada Gambar 5.

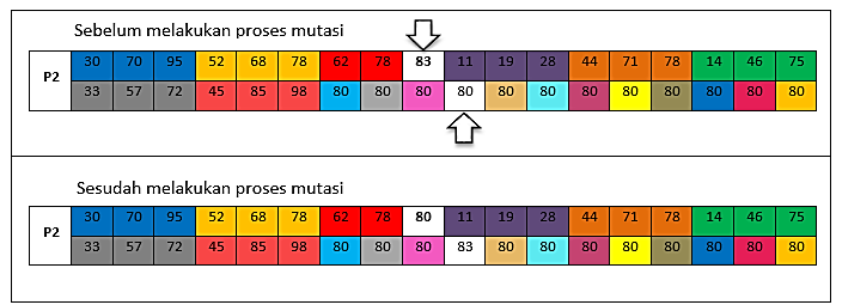

Gambar 5. Ilustrasi Proses Mutasi

Hasil offspring mutasi ditunjukkan Tabel 10.

Tabel 10. Hasil offspring Mutasi

\begin{tabular}{|c|c|}
\hline offspring & Kromosom \\
\hline C3 & $30,70,95,52,68,78,62,78,80,11,19,28,44,71,78,14,46,75$, \\
& $33,57,72,45,85,98,80,80,80,83,80,80,80,80,80,80,80,80$ \\
\hline
\end{tabular}

3. Evaluasi

Proses mengevaluasi suatu populasi dengan melihat seberapa baik individu tersebut. Fungsi penentu seberapa baiknya individu biasa disebut fungsi fitness. Dalam membangun nilai fungsi ini, sangat perlu diperhatikan karena akan mempengaruhi kinerja dari Algoritma Genetika (Zhang et al., 2016). Berikut hasil fitness gabungan yang ditunjukkan pada Tabel 11 .

Tabel 11. Hasil fitness Gabungan

\begin{tabular}{|c|l|c|}
\hline offspring & \multicolumn{1}{|c|}{ Kromosom } & fitness \\
\hline P1 & $35,65,90,54,66,76,64,76,81,12,18,27,47,68$, & 0,6373 \\
& $76,18,42,70,36,54,69,50,80,96,60,60,60,60$, & \\
& $60,60,60,60,60,60,60,60$ & \\
\hline P2 & $30,70,95,52,68,78,62,78,83,11,19,28,44,71$, & 0,7647 \\
& $78,14,46,75,33,57,72,45,85,98,80,80,80,80$, & \\
& $80,80,80,80,80,80,80,80$ & \\
\hline P3 & $40,60,85,56,64,74,66,74,79,13,17,25,64,66$, & 0,6412 \\
& $74,22,38,65,39,51,66,55,75,94,40,40,40,40$, & \\
& $40,40,40,40,40,40,40,40$ & \\
\hline C1 & $35,65,90,54,66,76,64,76,81,13,17,25,64,66$, & 0,7549 \\
& $74,22,38,65,39,51,66,55,75,94,40,40,40,40$, & \\
& $40,60,60,60,60,60,60,60$ & 0,7588 \\
\hline C2 & $40,60,85,56,64,74,66,74,79,12,18,27,47,68$, & \\
& $76,18,42,70,36,54,69,50,80,96,60,60,60,60$, & \\
& $60,40,40,40,40,40,40,40$ & 0,7549 \\
\hline C3 & $30,70,95,52,68,78,62,78,80,11,19,28,44,71$, & \\
& $78,14,46,75,33,57,72,45,85,98,80,80,80,83$, & \\
& $80,80,80,80,80,80,80,80$ & \\
\hline
\end{tabular}

4. Seleksi

Dalam membentuk generasi baru, diperlukan adanya kromosom baru dari pemilihan populasi induk yang ditentukan berdasarkan nilai fitness (Zhang et al., 2016). Penentuan fitness memberikan pengaruh pada tingkat konvergensi algoritma dan kualitas solusi yang diperoleh (Wang and Li, 2016).

Proses seleksi yang menggunakan metode elitism selection. Seleksi ini berdasarkan urutan tingkat fitness tertinggi sejumlah populasi yang telah didefinisikan(Galán et al., 2017). Berikut hasil seleksi ditunjukkan Tabel 12.

Tabel 12. Hasil Seleksi

\begin{tabular}{|c|l|c|}
\hline offspring & \multicolumn{1}{|c|}{ Kromosom } & fitness \\
\hline P2 & $30,70,95,52,68,78,62,78,83,11,19,28,44,71$, & 0,7647 \\
& $78,14,46,75,33,57,72,45,85,98,80,80,80,80$, & \\
& $80,80,80,80,80,80,80,80$ & \\
\hline C2 & $40,60,85,56,64,74,66,74,79,12,18,27,47,68$, & 0,7588 \\
& $76,18,42,70,36,54,69,50,80,96,60,60,60,60$, & \\
& $60,40,40,40,40,40,40,40$ & \\
\hline C1 & $35,65,90,54,66,76,64,76,81,13,17,25,64,66$, & 0,7549 \\
& $74,22,38,65,39,51,66,55,75,94,40,40,40,40$, & \\
& $40,60,60,60,60,60,60,60$ & \\
\hline C3 & $30,70,95,52,68,78,62,78,80,11,19,28,44,71$, & 0,7549 \\
& $78,14,46,75,33,57,72,45,85,98,80,80,80,83$, & \\
& $80,80,80,80,80,80,80,80$ & \\
\hline
\end{tabular}

\section{PENGUJIAN}

Pengujian dilakukan untuk memperoleh nilai parameter genetika terbaik untuk mendapatkan hasil yang optimal dalam waktu yang sewajarnya. Pengujian dilakukan dengan mengambil rata-rata hasil fitness terbaik dari 10 percobaan.

\subsection{Pengujian Ukuran Populasi}

Pengujian pada ukuran populasi ditentukan sebesar 10 populasi dengan kelipatan 10 mulai dari 
10 hingga 100. Nilai parameter untuk pengujian antara lain ukuran generasi sebesar 20, nilai $\mathrm{Cr}$ sebesar 0,8, dan nilai $\mathrm{Mr}$ sebesar 0,05 yang ditunjukkan Gambar 6.

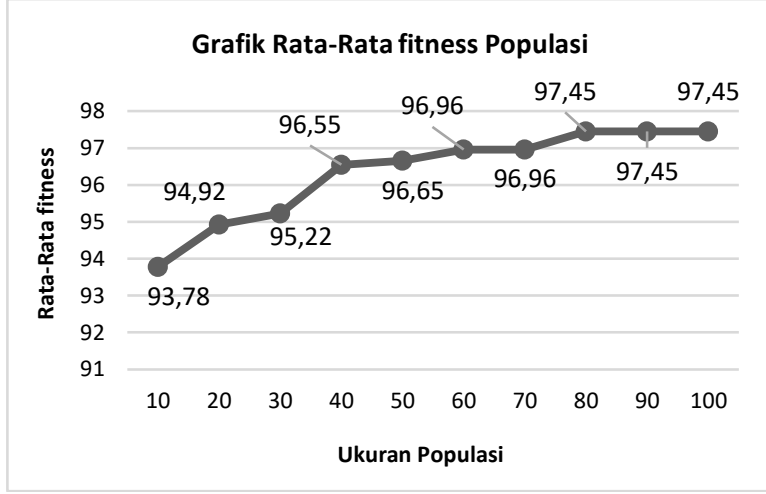

Gambar 6. Pengaruh Ukuran Populasi

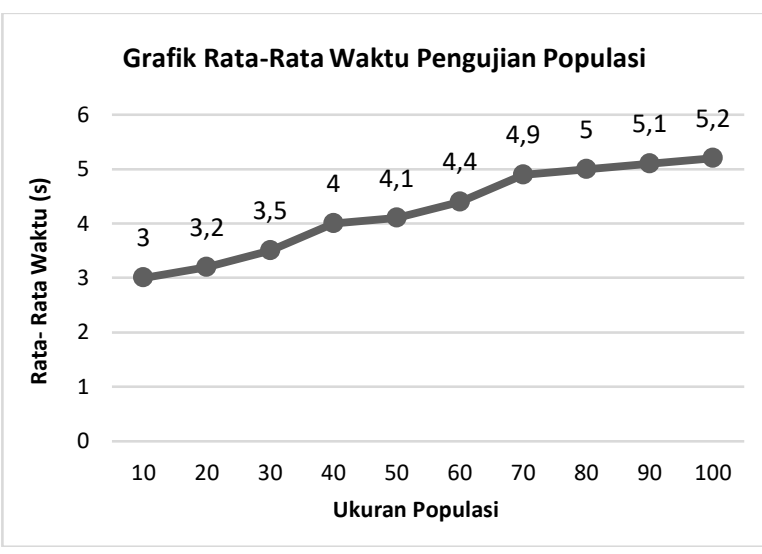

Gambar 7. Pengaruh Waktu Terhadap Ukuran Populasi

Dari Gambar 6 ditunjukkan bahwa grafik dari ukuran populasi 10 hingga 80 relatif mengalami peningkatan dari fitness $93,78 \%$ menuju fitness $97,45 \%$. Ukuran populasi lebih dari 80 tidak memberikan perbaikan fitness yang signifikan. Ukuran populasi yang terlalu besar tidak akan memberikan perbaikan solusi yang signifikan dan hanya membebani waktu komputasi. Pengaruh waktu terhadap jumlah ukuran populasi ditunjukkan pada Gambar 7. Sehingga solusi yang telah didapatkan terdapat pada ukuran populasi sebesar 80 .

\subsection{Pengujian Banyaknya Generasi}

Pengujian pada banyaknya generasi dengan variasi kelipatan 20 mulai dari 20 hingga 200. Nilai parameter dari ukuran populasi sebesar 80 dari hasil pengujian ukuran populasi terbaik. Nilai parameter lainnya seperti nilai $\mathrm{Cr}$ sebesar 0,8 dan nilai $\mathrm{Mr}$ sebesar 0,05 yang ditunjukkan Gambar 8 .

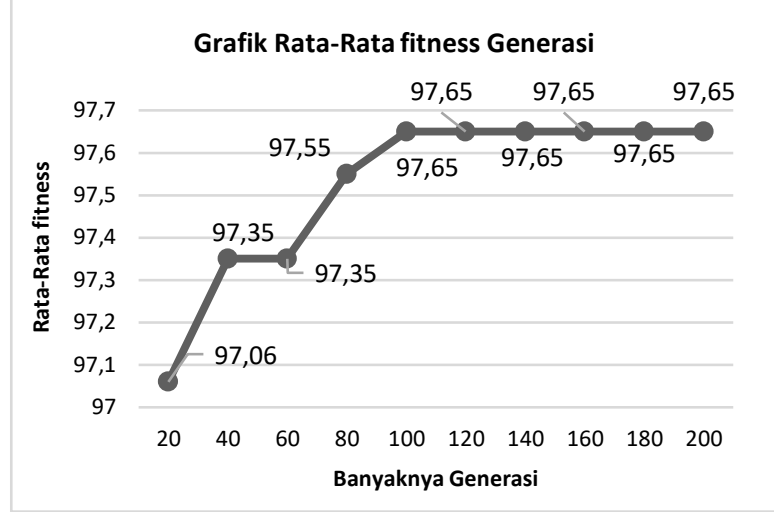

Gambar 8. Pengaruh Banyaknya Generasi

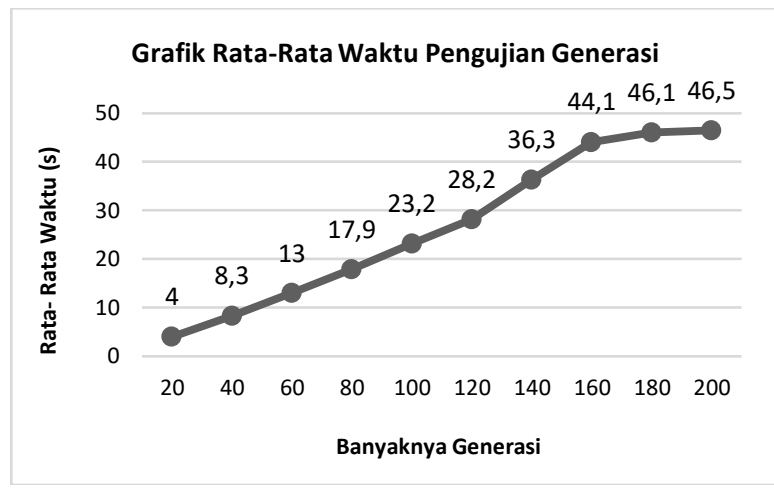

Gambar 9. Pengaruh Waktu Terhadap Banyaknya Generasi

Dari Gambar 8 ditunjukkan bahwa grafik dari ukuran generasi 20 hingga 100 relatif mengalami peningkatan dari fitness $97,06 \%$ menuju fitness 97,45\%. Tetapi pada generasi lebih dari 100 tidak memberikan perbaikan fitness yang signifikan. Pada titik tersebut telah terjadi kondisi konvergensi. Selain itu, jika jumlah generasi semakin besar, maka waktu yang dibutuhkan proses pengeksekusian juga akan semakin besar ditunjukkan pada Gambar 9 . Sehingga solusi yang telah didapatkan terdapat pada generasi ke 100 .

\subsection{Pengujian Kombinasi Cr dan $\mathrm{Mr}$}

Pengujian ini mencari nilai fitness setiap pengujian yang dilakukan sebanyak 9 kali. Nilai parameter ukuran populasi sebesar 80 dan ukuran generasi sebesar 100 ditunjukkan Gambar 10. 


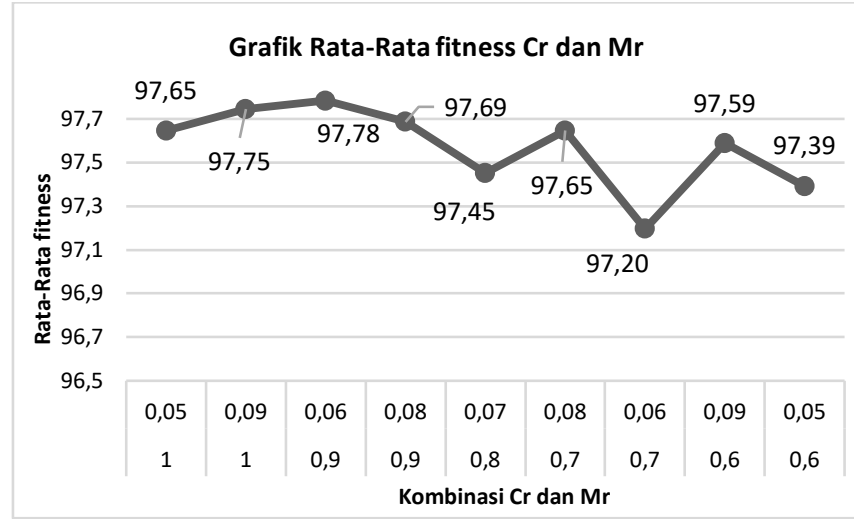

Gambar 10. Pengujian Kombinasi Cr dan Mr

Selain itu, diperlukan juga mengamati keberadaan fitness tertinggi pada setiap iterasi. Kemudian, menghitung nilai rata-rata iterasi tersebut untuk mendapatkan iterasi terbaik pada pengujian ini.

Tabel 13. Pengujian Iterasi Kombinasi $\mathrm{Cr}$ dan $\mathrm{Mr}$

\begin{tabular}{|c|c|c|c|c|c|c|c|c|c|c|c|c|}
\hline \multirow{2}{*}{\multicolumn{2}{|c|}{ Kombinasi }} & \multicolumn{10}{|c|}{ Iterasi } & \multirow{3}{*}{$\begin{array}{l}\text { Rata- } \\
\text { Rata }\end{array}$} \\
\hline & & \multicolumn{10}{|c|}{ Percobaan ke - } & \\
\hline $\mathrm{Cr}$ & $\mathrm{Mr}$ & 1 & 2 & 3 & 4 & 5 & 6 & 7 & 8 & 9 & 10 & \\
\hline 0,9 & 0,06 & 60 & 7 & 12 & 4 & 11 & 15 & 7 & 11 & 7 & 13 & 14,7 \\
\hline
\end{tabular}

Sehingga dapat disimpulkan dari Tabel 13 dan Gambar 6, kombinasi nilai $\mathrm{Cr}$ sebesar 0,9 dan nilai Mr sebesar 0,06 hanya memerlukan 15 iterasi untuk mendapatkan solusi yang optimal. Dan untuk iterasi selanjutnya nilai fitness tidak mengalami perubahan.

\subsection{Pengujian Parameter Terbaik}

Kombinasi parameter-parameter terbaik yang diperoleh dari pengujian sebelumnya digunakan ke dalam pengujian ini. Sehingga, parameter pengujian yang digunakan antara lain ukuran populasi sebesar 80, ukuran generasi sebesar 15, nilai Cr sebesar 0,9, dan nilai Mr sebesar 0,06. Pengujian yang dilakukan pada 51 data, menghasilkan jumlah akurasi data uji sebesar 50 karena pada data uji ke-24 dan ke-27 menghasilkan akurasi uji sebesar 0,5, lainnya akurasinya bernilai 1 . Sehingga proses optimasi fuzzy Tsukamoto menggunakan Algoritma Genetika memperoleh akurasi sebesar 98,04\% yang diperoleh dari perhitungan dengan Persamaan (7).

$$
\text { Akurasi }=\frac{\text { jumlah akurasi }}{\text { total data } \text { keseluruhan }} \times 100 \%
$$

Dibandingkan dengan data yang tanpa mengalami optimasi, hanya mendapatkan jumlah akurasi data uji sebesar 48,2. Akurasi pada data uji ke-2 sebesar 0,2, data uji ke-22 sebesar 0,5, data uji ke-27 sebesar 27, dan lainnya bernilai 1. Maka akurasi fuzzy Tsukamoto tanpa optimasi dihitung menggunakan Persamaan (7) menghasilkan akurasi sebesar $94,5 \%$. Sehingga akurasi proses optimasi fuzzy Tsukamoto menggunakan Algoritma Genetika telah mengalami peningkatan sebesar 3,54\%.

Selain itu, pengujian ini juga menghasilkan batasan terbaik setiap parameter kriteria gejala. Batasan tersebut diperoleh dari rata-rata hasil populasi yang terbentuk. Pada pengujian ini, ada 80 populasi yang terbentuk dan akan menjadi suatu solusi permasalahan. Disesuaikan dengan batasan gejala seorang pakar, maka nilai parameter tersebut akan dibulatkan sehingga bisa menjadi sebuah bilangan integer. Berikut hasil perbandingan batas atas rentang gejala pakar dengan metode yang ditunjukkan pada Tabel 14.

Tabel 14. Hasil Perbandingan Batas Atas Pakar Dengan Metode

\begin{tabular}{|c|c|c|c|c|}
\hline \multirow{2}{*}{$\begin{array}{l}\text { Kode } \\
\text { Gejala }\end{array}$} & \multirow{2}{*}{ Gejala } & \multirow{2}{*}{ Tingkat } & \multicolumn{2}{|c|}{ Batas Atas } \\
\hline & & & Pakar & Metode \\
\hline \multirow[t]{3}{*}{ G1 } & \multirow[t]{3}{*}{ Bengkak } & Normal & 50 & 32 \\
\hline & & Sedang & 75 & 36 \\
\hline & & Tinggi & 100 & 62 \\
\hline \multirow[t]{3}{*}{ G2 } & \multirow[t]{3}{*}{ Demam } & Normal & 60 & 34 \\
\hline & & Sedang & 70 & 58 \\
\hline & & Tinggi & 80 & 91 \\
\hline \multirow[t]{3}{*}{ G3 } & \multirow[t]{3}{*}{ Diare } & Normal & 65 & 40 \\
\hline & & Sedang & 80 & 44 \\
\hline & & Tinggi & 85 & 61 \\
\hline \multirow[t]{3}{*}{ G4 } & \multirow[t]{3}{*}{ Diare berdarah } & Normal & 15 & 1 \\
\hline & & Sedang & 20 & 16 \\
\hline & & Tinggi & 30 & 29 \\
\hline \multirow[t]{3}{*}{ G5 } & \multirow[t]{3}{*}{ Keluar ingus } & Normal & 60 & 20 \\
\hline & & Sedang & 75 & 60 \\
\hline & & Tinggi & 80 & 69 \\
\hline \multirow[t]{3}{*}{ G6 } & \multirow[t]{3}{*}{ Kurus } & Normal & 30 & 19 \\
\hline & & Sedang & 50 & 28 \\
\hline & & Tinggi & 80 & 76 \\
\hline \multirow[t]{3}{*}{ G7 } & \multirow{3}{*}{$\begin{array}{c}\text { Nafsu makan } \\
\text { berkurang }\end{array}$} & Normal & 45 & 20 \\
\hline & & Sedang & 60 & 59 \\
\hline & & Tinggi & 75 & 74 \\
\hline \multirow[t]{3}{*}{ G8 } & \multirow[t]{3}{*}{ Sesak nafas } & Normal & 80 & 62 \\
\hline & & Sedang & 90 & 63 \\
\hline & & Tinggi & 100 & 81 \\
\hline G9 & Berbau busuk & Ya & 100 & 35 \\
\hline G10 & Bulu berdiri & $\mathrm{Ya}$ & 100 & 32 \\
\hline G11 & Bulu kusam & $\mathrm{Ya}$ & 100 & 50 \\
\hline G12 & Bulu rontok & $\mathrm{Ya}$ & 100 & 71 \\
\hline G13 & Gatal-gatal & $\mathrm{Ya}$ & 100 & 65 \\
\hline G14 & $\begin{array}{l}\text { Keluar lendir } \\
\text { vulva }\end{array}$ & $\mathrm{Ya}$ & 100 & 77 \\
\hline G15 & Kembung & $\mathrm{Ya}$ & 100 & 27 \\
\hline G16 & Kulit kasar & $\mathrm{Ya}$ & 100 & 69 \\
\hline G17 & Mamae keras & $\mathrm{Ya}$ & 100 & 47 \\
\hline G18 & Muncul belatung & $\mathrm{Ya}$ & 100 & 54 \\
\hline G19 & Pincang & $\mathrm{Ya}$ & 100 & 42 \\
\hline G20 & Plasenta tertinggal & Ya & 100 & 19 \\
\hline
\end{tabular}

Dilihat dari Tabel 14, ditunjukkan bahwa keseluruhan gejala dari hasil metode cenderung mengalami penyempitan batasan. Hanya gejala demam (G2) kriteria tinggi saja yang mengalami pelebaran batasan. Dengan batasan yang lebih disempitkan, memungkinkan untuk menaikkan hasil akurasi. Proses diagnosis yang menggunakan batasan dari hasil metode Algoritma Genetika memperoleh hasil akurasi yang lebih tinggi dibandingkan dengan batasan dari pakar.

\section{KESIMPULAN}

Optimasi fuzzy Tsukamoto pada diagnosis penyakit sapi potong dengan Algoritma Genetika 
dapat digunakan untuk menyelesaikan permasalahan pendeteksian penyakit sapi. Solusi tersebut menghasilkan nilai batasan gejala penyakit yang optimal dengan akurasi sebesar 98,04\%. Akurasi tersebut mengalami peningkatan sebesar 3,54\% sesudah dilakukannya optimasi. Adapun parameter genetika terbaik yang diperoleh melalui serangkaian percobaan dengan berbagai macam kombinasi nilai. Nilai terbaik untuk ukuran populasi sebesar 80 , banyaknya generasi sebesar 15 , nilai $\mathrm{Cr}$ sebesar 0,9 , dan nilai Mr sebesar 0,06. Selain itu, batasan terbaik yang diperoleh dari cenderung lebih sempit dari batasan yang diperoleh dari pakar.

Penelitian selanjutnya diharapkan data penyakit yang tidak memiliki data gejala yang spesifik, lebih baik tidak digunakan atau informasi gejalanya lebih diperinci kembali. Sehingga, dapat memperoleh akurasi yang lebih tinggi dengan diagnosis yang akurat.

\section{DAFTAR PUSTAKA}

ADELI, M., BIGDELI, N. \& AFSHAR, K. 2013. New Hybrid Hepatitis Diagnosis System Based On Genetic Algorithm And Adaptive Network Fuzzy Inference System. 21st Iranian Conference on Electrical Engineering (ICEE), 1-6.

AGARWAL, S. \& VASAN, A. 2016. Computational Strategy for Structural Analysis, Design, and Optimization of Trusses Using Genetic Algorithm and Particle Swarm Optimization. IEEE 6th International Conference on Advanced Computing (IACC), 203-207.

AHMED, S., KABIR, M. T., MAHMOOD, N. T. \& RAHMAN, R. M. 2014. Diagnosis Of Kidney Disease Using Fuzzy Expert System. 8th International Conference on Software, Knowledge, Information Management and Applications (SKIMA), 18.

ALHARBI, A. \& TCHIER, F. 2015. A FuzzyGenetic Algorithm Method for the Breast Cancer Diagnosis Problem. ADVCOMP 2015: The Ninth International Conference on Advanced Engineering Computing and Applications in Sciences, 122-127.

ANGGRAENI, W., MUKLASON, A., ASHARI, A. F., WAHYU, A. \& DARMINTO. 2013. Developing Mobile Intelligent System for Cattle Disease Diagnosis and First Aid Action Suggestion. Seventh International Conference on Complex, Intelligent, and Software Intensive Systems (CISIS), 117 121.

ARMANDA, R. S. \& MAHMUDY, W. F. 2016. Penerapan Algoritma Genetika Untuk Penentuan Batasan Fungsi Kenggotaan Fuzzy Tsukamoto Pada Kasus Peramalan
Permintaan Barang. Jurnal Teknologi Informasi dan Ilmu Komputer, 3, 169-173.

AZIZAH, E. N., CHOLISSODIN, I. \& MAHMUDY, W. F. 2015. Optimasi Fungsi Keanggotaan Fuzzy Tsukamoto Menggunakan Algoritma Genetika Untuk Penentuan Harga Jual Rumah. Journal of Enviromental Engineering and Sustainable Technology, 2, 79-82.

BALA, A. \& SHARMA, A. K. 2015. A Comparative Study Of Modified Crossover Operators. Third International Conference on Image Information Processing (ICIIP), 281-284

BIYOUKI, S. A., TURKSEN, I. B. \& ZARANDI, M. H. F. 2015. Fuzzy Rule-Based Expert System For Diagnosis Of Thyroid Disease. IEEE Conference on Computational Intelligence in Bioinformatics and Computational Biology (CIBCB), 1-7.

ESMIN, A. A. A. \& LAMBERT-TORRES, G. 2007. Evolutionary Computation Based Fuzzy Membership Functions Optimization. IEEE International Conference on Systems, Man and Cybernetics, 823-828.

FERNANDEZ-MILLAN, R., MEDINAMERODIO, J.-A., PLATA, R. B., MARTINEZ-HERRAIZ, J.-J. \& GUTIERREZ-MARTINEZ, J.-M. 2015. A Laboratory Test Expert System For Clinical Diagnosis Support In Primary Health Care. Applied Sciences, 5, 222-240.

GALÁN, C. O., LASHERAS, F. S., JUEZ, F. J. D. C. \& SÁNCHEZ, A. B. 2017. Missing Data Imputation Of Questionnaires By Means Of Genetic Algorithms With Different Fitness Functions. Journal of Computational and Applied Mathematics, 311, 704-717.

JUNINGDIYAH, P., DEWI, C. \& INDRIATI. 2014. Optimasi Fungsi Keanggotaan Fuzzy Menggunakan Algoritma Particle Swarm Optimization (PSO) Pada Sistem Inferensi Fuzzy Penentuan Jurusan Siswa SMA. DORO: Repository Jurnal Mahasiswa PTIIK Universitas Brawijaya, 4.

KALER, J. \& GREEN, L. E. 2013. Sheep Farmer Opinions On The Current And Future Role Of Veterinarians In Flock Health Management On Sheep Farms: A Qualitative Study. Preventive Veterinary Medicine, 112, 370-377.

KAYA, M. 2011. The Effects Of Two New Crossover Operators On Genetic Algorithm Performance. Applied Soft Computing, 11, 881-890.

KUMAR, A. \& CHATTERJEE, K. 2016. An Efficient Stream Cipher Using Genetic Algorithm. International Conference on Wireless Communications, Signal 
Processing and Networking (WiSPNET), 2322-2326.

MAHMUDY, W. F. 2014. Optimisation of Integrated Multi-Period Production Planning and Scheduling Problems in Flexible Manufacturing Systems (FMS) Using Hybrid Genetic Algorithms. School of Engineering, University of South Australia.

MEZA-PALACIOS, R., AGUILAR-LASSERRE, A. A., UREÑA-BOGARÍN, E. L., VÁZQUEZ-RODRÍGUEZ, C. F., POSADA-GÓMEZ, R. \& TRUJILLOMATA, A. 2017. Development Of a Fuzzy Expert System For The Nephropathy Control Assessment in Patients with Type 2 Diabetes Mellitus. Expert Systems with Applications, 72, 335-343.

NISAK, A., SOEBROTO, A. A. \& FURQON, M. T. 2015. Sistem Pakar Diagnosa Penyakit Pada Sapi Potong Dengan Metode Fuzzy Inference System (FIS) Tsukamoto (Studi Kasus: Pos Keswan Kabupaten Nganjuk). DORO: Repository Jurnal Mahasiswa PTIIK Universitas Brawijaya, 6.

OMISORE, M. O., SAMUEL, O. W. \& ATAJEROMAVWO, E. J. 2015. A Genetic-Neuro-Fuzzy Inferential Model For Diagnosis Of Tuberculosis. Applied Computing and Informatics, 13, 27-37.

PARTHIBAN, L. \& SUBRAMANIAN, R. 2009. An Intelligent Agent For Detection Of Erythemato- Squamous Diseases Using CoActive Neuro-Fuzzy Inference System And Genetic Algorithm. International Conference on Intelligent Agent \& MultiAgent Systems. IAMA, 1-6.

PURNOMO, H. \& KUSUMADEWI, S. 2010. Aplikasi Logika Fuzzy Untuk Pendukung Keputusan. Graha Ilmu: Yogyakarta.

PUTRA, A. A. \& MUNIR, R. 2015. Implementation Of Fuzzy Inference System In Children Skin Disease Diagnosis Application. International Conference on Electrical Engineering and Informatics (ICEEI), 365370.

RAMUNA, M. D. T. \& MAHMUDY, W. F. 2015. Optimasi Persediaan Barang Dalam Produksi Jilbab Menggunakan Algoritma Genetika. DORO: Repository Jurnal Mahasiswa PTIIK Universitas Brawijaya, 5.

SAMUEL, A. E. \& BALAMURUGAN, M. 2012. Fuzzy Max-Min Composition Technique In Medical Diagnosis. Applied Mathematical Sciences, 6, 1741-1746.

SCHIFF, G. D. 2008. Minimizing Diagnostic Error: The Importance Of Follow-Up And Feedback. The American journal of medicine, 121, S38-S42.
SEETARAM, J. \& KUMAR, P. S. 2016. An Energy Aware Genetic Algorithm Multipath Distance Vector Protocol For Efficient Routing. International Conference on Wireless Communications, Signal Processing and Networking (WiSPNET), 1975-1980.

SURATNO, SUDJADI \& TRIWIYATNO, A. 2011. Pengaruh Perbedaan Tipe Fungsi Keanggotaan Pada Pengendali Logika Fuzzy Terhadap Tanggapan Waktu Sistem Orde Dua Secara Umum. Jurusan Teknik Elektro Fakultas Teknik UNDIP.

THAMRIN, F., SEDIYONO, E. \& SUHARTONO, S. 2014. Studi Inferensi Fuzzy Tsukamoto Untuk Penentuan Faktor Pembebanan Trafo PLN. JURNAL SISTEM INFORMASI BISNIS, 2, 001-005.

TYAS, R. D. O., SOEBROTO, A. A. \& FURQON, M. T. 2015. Pengembangan Sistem Pakar Diagnosa Penyakit Sapi Potong Dengan Metode Fuzzy K-Nearest Neighbour. Journal of Enviromental Engineering and Sustainable Technology, 2, 58-66.

UTOMO, M. C. C. \& MAHMUDY, W. F. 2015. Penerapan FIS-Tsukamoto untuk Menentukan Potensi Seseorang Mengalami Sudden Cardiac Death. SESINDO 2015.

WANG, B. \& LI, J. Load Balancing Task Scheduling Based On Multi-Population Genetic Algorithm In Cloud Computing. 35th Chinese Control Conference (CCC), 2016, 27-29 July. 2016. 5261-5266.

ZAMRONI, M. R. 2014. Pemanfaatan Metode Logic Mamdani Untuk Spk Penerimaan Beasiswa Di Sma Muhammadiyah 10 Sugio. Jurnal Teknika 6.

ZHANG, W., GUO, F., SONG, T., MENG, X. \& ZHANG, Q. 2016. On Specific Harmonic Elimination Pwm Of Inverter Based On Genetic Algorithm. 35th Chinese Control Conference (CCC), 9207-9211.

ZHOU, H. \& SONG, M. 2016. An Improvement Of Partheno-Genetic Algorithm To Solve Multiple Travelling Salesmen Problem. IEEE/ACIS 15th International Conference on Computer and Information Science (ICIS), 1-6. 